\title{
The Road Not Taken by Robert Frost or Empathic Cognition and the Role of Symbols in Comprehension of Poetry
}

\author{
Irina Kladenova \\ MBOU of the City of Kurgan "Gymnasium No. 47”, Kurgan, Russia
}

\begin{abstract}
The role of empathic cognition is very great for philosophers and philosophy in general and for ordinary people. Empathic cognition gives people a chance "to let" the emotions of the Other "go" into their minds. Empathic cognition is based on so-called co-suffering and in-sensation of the feelings of the Other or Others. Clots of energy or certain energy units are formed in consciousness of each person, they are called "subjective representants". It is possible to understand the Other or Others and to decipher the main idea of the poem (if the task to work on translation is given) and to express it in the native language if to find out not only the meanings of the words but the symbols the author has used in his poem. The reader "goes into" the world of the author trying to be near the author and trying to grasp what the author felt working on the poem. There is something what gives us a possibility to enter into the world of a creative personality. This "something" is empathic cognition.
\end{abstract}

Keywords: empathic cognition, the Other (the Others), subjective representant, symbols, poetry

\section{Introduction}

Each of us is in need of communication and necessity to comprehend the Other or Others during the whole life. Sometimes it is very easy to find the way to this or that Other; sometimes the problem of understanding the Other is unsolved because people are different in everything and some living beings do not have any wish or desire to find their way to Others. Very often they are called "the ones having the elephant's skin" and it is useless to try to prove them that it is very important especially for them to understand the Other or Others.

Literature and poetry, music, arts and ballet, films and cartoons, nature, the man in general, and etc., may give practically each of us a possibility "to take" emotions of the Other, "to listen to" him, "to feel" and at last even "to touch the soul" of that Other in the process of "deciphering" of the personal "I" of this or that author, composer, or painter. Empathic cognition gives people a chance "to let" the emotions of the Other "go" into their minds.

\section{Empathic Cognition as It Is}

The role of empathic cognition is very great for ordinary people, for philosophers and philosophy in general. Nowadays empathic cognition is a new page in philosophy especially for those who are eager to understand not only the world around him but to understand the Other, his inner world, his appreciation of the surroundings and people. Empathic cognition is based on so-called co-suffering and in-sensation of the feelings of the Other or Others. Clots of energy or certain energy units are formed in consciousness of each person. 
Professor Boris Shalutin (2001) (Kurgan State University, Russia) offers to call them "subjective representants". He states,

Subject may regard for the Other as for Subject if that Other is represented in psychics in his subjective quality somehow. The image of the body of Subject is not equal to the representant of Subject-it is only the image of a body among bodies (or the image of the body among images of the bodies), an obstacle among obstacles. (p. 113)

"Subjective representants" give each person a chance to comprehend and to perceive the inner world of the Other. It means that the appreciation of the Other and my appreciation of a person, "I" of that Other and my individual "I" may be different.

I can only predict the way of behaviour of that Other. Two variants are possible in this situation: I may understand his way of behaviour or I may be mistaken. In my mind that Other "expresses" his personal opinion, he "acts", "agrees", or "disagrees".

\section{How "to Open the Door"?}

Why is it so important for everyone "to take" someone's emotions? What may help each of us "to see" the Other and to adopt him? What may help my students to find the key and to open the door leading to the Other who is considered to be a famous poet, writer, composer, cartoon-maker, director, actor, artist, ballet-master, etc., and to the works of that Other.

The task to read and to translate the poem of a foreign author is always very complicated for the students. To comprehend the poem is possible only for the reader who is ready to "to dive" into the content of the text, who knows his mother tongue very well and who is eager to understand that Other whom the poem was written by. It is possible to decipher the main idea of the poem and to express it in the native language if to find out not only the meanings of the words but the symbols the author has used in his poem. The reader "goes into" the world of the author trying to be near the author and trying to grasp what the author felt working on the poem. There is something what gives us a possibility to enter into the world of a creative personality.

\section{New Approach to the Translation}

Each one learning foreign languages understands that it is very difficult to "hear" the real voice of the poet. Using empathic cognition the translator experienced or inexperienced, young or old understands easier the thoughts, expectations, and hopes of the poet who lived centuries ago.

Robert Frost is an outstanding American poet, who (as many other poets) "shares" his own way of appreciation of his poems with his readers and translators, who "helps" them to understand the inner-sense of what he wanted to say to all those who wish to grasp the poet's ideas and thoughts. It is very interesting and useful for the translator to analyse the symbols the poet used in his poems.

What should a teacher do to help his students to open the world of poetry, to make them "hear" the heart beat of the poet who lived many years ago in the country which is very far from Russia? How "to come closer" to the poet and the poet's appreciation of life? How to enter into the atmosphere of the poem and to understand the point of view of the author?

\section{How "to Take the Road"?}

Here is the poem by Robert Frost. It is usually given to the students of senior grades of gymnasium who are interested in poetry and linguistics. The students are to comprehend and try to translate it from English into 
Russian. They are to try "to decipher" not only the content of the poem using their own imagination, their intellect, and their feelings. The students are to grasp the inner world of the poet, to analyze the poet's feelings and thoughts, his life credo.

\author{
The Road Not Taken \\ Two roads diverged in a yellow wood, \\ And sorry I could not travel both \\ And be one traveler, long I stood \\ And looked down one as far as I could \\ To where it bent in the undergrowth; \\ Then took the other, as just as fair, \\ And having perhaps the better claim, \\ Because it was grassy and wanted wear; \\ Though as for that the passing there \\ Had worn them really about the same, \\ And both that morning equally lay \\ In leaves no step had trodden black. \\ Oh, I kept the first for another day! \\ Yet knowing how way leads on to way, \\ I doubted if I should ever come back. \\ I shall be telling this with a sigh \\ Somewhere ages and ages hence: \\ Two roads diverged in the wood, and I \\ I took the one less traveled by, \\ And that made all the difference. (John, 1979, pp. 224-225)
}

What to do first of all: to start the work on the text of the poem trying to copy out new words and looking through the poem very attentively?

\title{
Symbolic Origin of Symbols
}

There are an enormously great number of symbols in the poem and they will help any investigator to make the translation. Symbols play a very important role in the appreciation of the world and the people in this world. Each poem and a piece of music, each cartoon and each film, each picture and each icon, each ballet and each opera and etc., are full of symbols. Philosophical Encyclopaedic Dictionary says, "Symbol (gr. Simbolon) - means a distinctive token; sign, image personifying some idea; seen, more seldom heard, a formation to which an exact group of people attaches a great importance which is not connected with the essence of this formation" (Ivanov, 2006, Moscow, p. 413).

There are four paragraphs in the poem and each part of it has five lines. Why did the poet divide his poem into four parts? Number four is considered to be the beginning of something. It also means something which is clean. It is the symbol of life and it is the symbol of cross which is given to each person coming into this world.

Why are there five lines in each part of the poem? "Five" symbolizes a man whose head, hands, and legs form a star. Five means inspiration, individuality, microcosm, and inner world of a man. Number five is the symbol of desire of a man to live. It has the meaning of sufferings and the wish to survive in difficulties.

If a reader knows the meaning these symbols or "feels" the meaning of these notions, he may come to the conclusion that the poem is devoted to the man and his fate in the world. 


\section{“Deciphering” Symbols}

At the very beginning of the poem, Robert Frost uses number two (two roads). The symbol of "two" is an angle and it also means a conflict. "Two" is a symbol of choice and contradiction. Everyone knows that without them it is simply impossible for a man to cover a long path which has the name of life. The author makes the reader come to his own choice: to be or not to be, to go on, to act or not to change anything, to hesitate during the whole life doing nothing. "Two" means fire and water, good and evil, light and darkness. It is the choice of the life road. "Two" is something which has never been learned and studied by the man.

A yellow wood... Why is it yellow? Why has the poet chosen this very color? "Yellow" means autumn, life which is full of events; it means life experience, knowledge, and skills. It is a symbol of the person whose life is rich and full; it is the symbol of the road which is not over. If to pay attention to the date when the poem was written it appears that Robert Frost was an elderly man that time, full of experience and wisdom.

Looking through the poem a reader finds out the symbol of a road. The road may symbolize a fate of the Man, the story of his life from the first till the very last moments of it. The road is the place of meetings and partings and new meetings and new partings and so on and so forth. It may be the image of Time which cannot be stopped. It may be the symbol of a pilgrim going along the road to his Teacher. The road which is chosen by the author only seems to be easy to go along. Having been chosen the road "shows" its character: There are a lot of difficulties there. Each of us knows it and meets them during the life. There are a lot of fortunes and misfortunes on the way and it is the duty of everyone to find the way-out and to solve all these problems. It is very difficult to choose the road but if the choice is maid it is necessary to go, not to stop, to fight trying to win. The poet states that it is better not to complain about the road which has not been chosen. It is better to continue the way, to meet new people, to meet new paths, and to choose a new road again and again.

One more symbol is used by the author here - a wood. A wood is the place which may be connected with serious danger: It is possible to lose the path and not to find it. On the other hand, a wood is the place where a gifted person may be hidden from secular vanity of vanities. It is the place where he has a chance to comprehend the past, present, and future.

Each wood consists of trees. A tree (the roots of which are in the ground and the brunches of which stretch to the sky) is the symbol of life, the symbol of desire to cognize unknown. A tree may also symbolize a Man. Both a tree and a man are the "creatures" which exist between heaven and earth. They are in the centre of the world; they are growing and changing with the world around and both are considered to be the most powerful symbols of personification of vitality.

Now it is easy for a reader to form the main idea of the poem. It is easy to "feel" that the life of the poet was hard and "to see" how difficult the road of the author was. The reader is "near" Robert Frost, he "listens to" the poet's words and he "hears" him, he "feels" the poet's pain and mood. The reader lets the emotions of the author become his own ones. So-called energy center or "subjective representant" appears in the mind of a reader. It helps the reader to comprehend the author, his thoughts and ideas, the images which were used by the poet to share his ideas with the reader.

\section{Conclusion}

There is a great number of interpretations and divergences in comprehension of some parts this poem. But 
the main idea of it is clear for the one who started to work on the translation of the poem from English into Russian.

When the work on the translation is over, it happens that young translators are ready to write their own variant and to express their own way of appreciation of thoughts and ideas of the author. They formulate the main idea of the poem easily. They feel how arduous the way of the poet was. They realise that there are a lot of problems on the life road of the poet. It is quite clear for the students that the poet is a real fighter. He is ready to crush all the obstacles, to become a winner, and to solve his own problems. Young translators become a little bit sure in themselves. They understand themselves better. They try to peep into their own inner world; they teach themselves to feel and to understand Others. They are ready to appreciate themselves. They are near the outstanding poet, they do not only listen to him, and they hear him very well.

And the English poem by Robert Frost turns into the Russian translation:

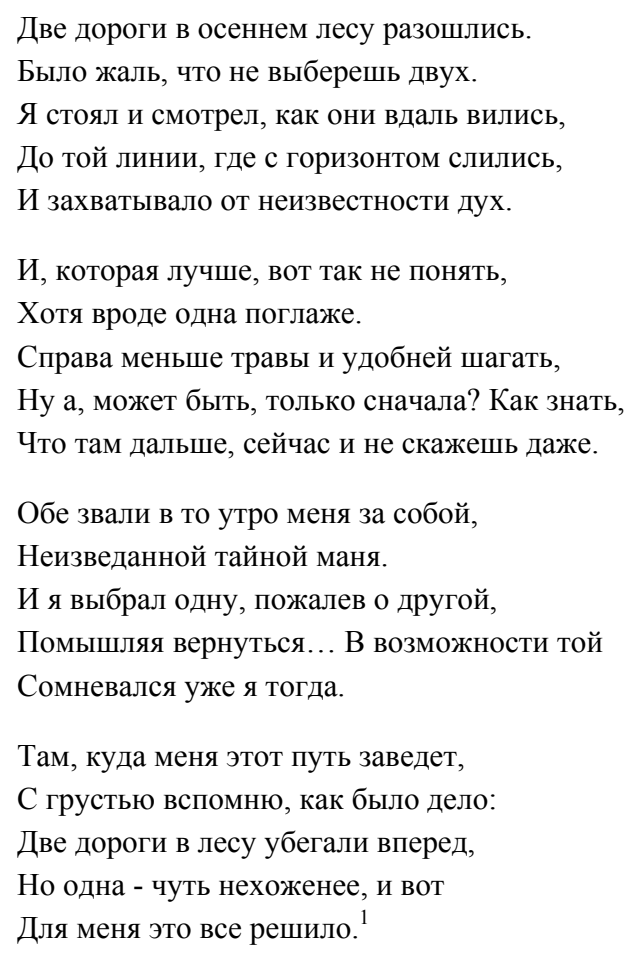

The work is over. The images created by Robert Frost are saved. The style of the original is not changed.

It is Robert Frost who explained the person reading and translating the poem his own problems. It is he who opened his soul and his world for the reader and translator. It is he who presented his experience, his wisdom and his truth and gave a chance for the representatives of a younger generation to feel that it is possible to understand the Other and to know for sure that each of us is the Other for Others.

\section{References}

Bochkaryeva, S. V. (2011). Thoughts about empathic cognition. Kurgan: KGU.

Grachyeva, L. V. (1992). Bringing feelings up. St.Petersburg: SPb-Press.

Ivanov, I. I. (2006). Filosofskiy intsiklopedicheskiy slovar (Philosophical encyclopaedic dictionary). M: INFRA-M.

John, B. (1979). The poetry of Robert Frost. New York: Henry Holt \& Company.

${ }^{1}$ Translated by U. Safonova, Form 11 of Gymnasium No. 47, Kurgan. 
Shalutin B. S. (2001). Soperezhivanie kak osnovanie ratsionalnogo poznaniya/Lichnost v sovremennom mire (sotsialno-psikhologicheskie problemy) (Co-experience as the foundation of the rational cognition/personality in the modern world (Socio-psychological problems)). In Materialy mezhdunarodnoi konferentsii 24-25 aprelya (Proc. of the International Conference of April 24-25), KGU, Kurgan.

Vygotskiy, L. S. (2014). Psychology. Moscow: EXMO-Press. 